\title{
Evaluating the Impact of Microfinance at the Individual Level in Albania, Particularly in the Region of Vlora and Fier
}

\author{
Oltiana Muharremi ${ }^{1}$, Edlira Luçi ${ }^{2}$, Filloreta Madani ${ }^{1} \&$ Erald Pelari ${ }^{1}$ \\ 1 Department of Finance, University of Vlora, Albania \\ 2 Department of Finance, University of Tirana, Albania \\ Correspondence: Oltiana Muharremi1, Department of Finance, University of Vlora, Albania. E-mail: \\ olta.muharremi@gmail.com
}

Received: May 3, 2018; Accepted: May 11, 2018; Published: June 7, 2018

\begin{abstract}
Microfinance is defined as the provision of financial services such as micro-credit, micro savings, and micro insurance for individuals with low income. Although access to micro credit is seen as a right to have credit, it rather represents a right to development and economic initiatives that could change the borrower's way of life. The purpose of this article is to examine the impact of microfinance loans in improving the living conditions of borrowers. This study is based on an empirical investigation of 384 structured questionnaires directed at microfinance institutions in the regions of Vlore and Fier, Albania.
\end{abstract}

Jel Classification: G21, G23, I31

Keywords: Microfinance, borrower, empowerment, living conditions, income

1. Introduction

\subsection{Access to Financial Services}

The poor people are excluded from formal financial systems. Exclusion ranges from partial exemption in developed countries to total or nearly complete exclusion in less developed countries. In the absence of accessible formal financial services, the poor have developed a wide variety of community-based informal financial arrangements to meet their financial needs. In addition, during the past two decades, a growing number of formal sector organizations (non-governmental, governmental and private) are created in order to meet these needs.

Financial inclusion is widely recognized as important in reducing poverty and achieving economic growth. It is not an end in itself, but serves as a tool and there is increasing evidence that it brings significant benefits to individuals. Studies show that when people participate in the financial system, they are able to start and expand their businesses, invest in education, manage and handle financial risks. Access to financial accounts, savings accounts, payment mechanisms, and increased savings, empowers women and increases productive investments and consumption. Access to credit has positive effects on consumption as well as employment possibilities and income, and in some aspects of mental health and future prospects. The benefits go beyond individuals, because a greater access to financial services for them and their firms can help reduce income inequality and accelerate economic growth.

The World Bank in 2011 financed a project to create a database on global financial inclusion (Global Findex), whereby it will provide comparable indicators, showing how people around the world save, borrow, make payments, and manage risk. Between 2011 and 2014, 700 million adults were new holders of bank accounts, while those who do not have an account fell by $20 \%$ to 2 billion people. Percentage of adults who own an account has increased in almost every country, however, the rate of accounts ownership continue to vary widely around the world. In OECD economies with high income, account ownership it is very high: $94 \%$ of adults reported an account in 2014 while in developing economies only 54\%. There are large differences between developing regions, where the dispersion of new accounts ranges from 14\% in the Middle East to $69 \%$ in East Asia and the Pacific. In Albania $38 \%$ of households report having an account and $34 \%$ of those are women. 
Table 1. Account penetration based on countries

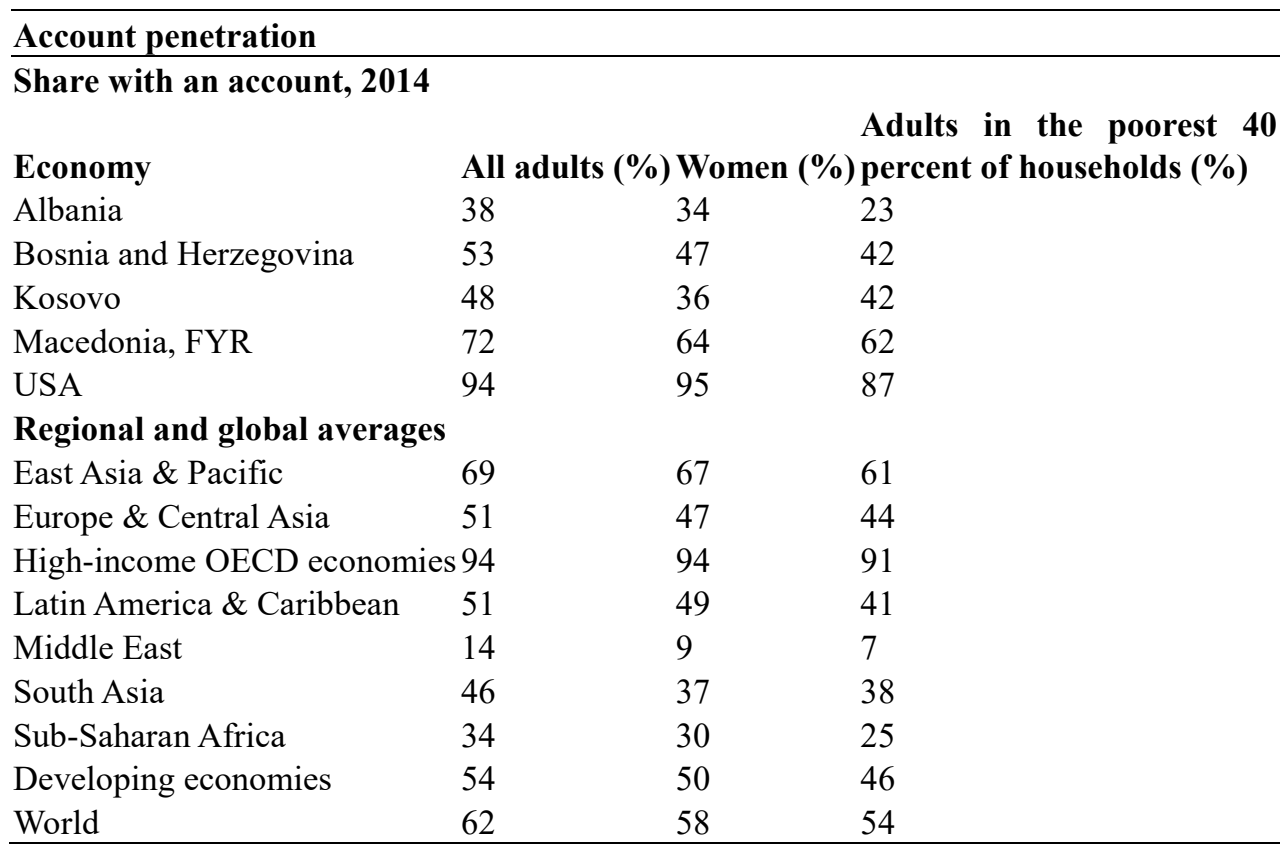

Notes: Data for the poorest 40 percent of households are based on household income quintiles within economies

Source: The Global Findex Database 2014. Measuring Financial Inclusion around the World. pg. 84.

http://documents.worldbank.org/curated/en/187761468179367706/pdf/WPS7255.pdf

\section{Literature Review}

Microcredit is determined by the small amounts given as loans to its intended users (young entrepreneurs or families with low income); its use functions as potential income generation and promotion of entrepreneurship, improves the lives of communities, education; while terms and conditions of microcredit are flexible, accessible, and suitable for local conditions. Lending programs target various credit applicants and business investors, and consequently their lending strategies and repayment plans are flexible (Srinivas 2015(Note 1)).

Microcredit, as an element of microfinance is a success model developed and widespread in many countries around the world, as it serves as an instrument in the fight against poverty. Literature, research papers and reports focus on the impact individual projects, mostly institutions such as the World Bank, EBRD and others, have on poverty for the beneficiaries by isolating and studying changes produced by receiving microfinance loans and by measuring the impact it has on the living conditions of the borrowers. Most MFIs in the world have a very low degree of default, it almost never exceeds 5\%, one reason why to study the difficulties arising at the time of loan repayment for some of the borrowers often go unsearched (Note 2).

The poorest clients are less likely to have benefits from microfinance then the wealthy clients (Hulme \& Mosley, 1996; Hulme, 2000; Copestake, 2002, 2005; Johnson, 2005; Wright -Revolledo, 2005). More likely clients who have benefited from microfinance are socially involved and have professional experience (Doligez et al., 2013) while the impact of micro borrowing is on average $80 \%$ higher compared with poorer clients (Copestake et al., 2005). In addition, poorer clients benefit less from microfinance, but they also could experience negative effects more often (Odell, 2010). Such results for developing countries are in line with results in developed countries. In France, Balkenhol and Guézennec (2013) have shown that long-term unemployed borrowers have benefited less from business microcredit loans and have a higher level of failure than borrowers who were former independent workers. Regarding consumer microcredit Gloukoviezoff and Rebière (2013) have found that employed borrowers were more likely to benefit from the positive effect of professional inclusion (i.e. continuing their work, or gaining a better position) than unemployed borrowers, who tried to find a job.

Such variety on the impact microfinance has depends on the customer profile mainly due to the fact that different clients have different needs (i.e. mixture of microfinance services) and need various financial services to cater to their requests. For example, while microcredit in developing countries are usually given to finance a productive 
business, they also are often used by borrowers in such counterproductive ways such as: increasing personal consumption, dealing with emergencies, and purchase of assets and payment of prior expenses (Copestake and Williams, 2011, Duvendack et al., 2011).

Augsburg et al. (2015) conducted an RCT in Bosnia and Herzegovina on a sample of nearly 1,200 borrowers, to assess the impact of large MFIs offering individual lending products to 'marginal' clients. After an observation period of 14 months the authors found no significant impact on household income. They reported evidence of a significant increase in the labour supply of 16- to 19-year-olds, they detected a significant decrease in weekly food and non-food consumption and savings (including 'temptation goods' such as alcohol and tobacco).

Ghalib et al. (2015) conducted a study on six MFIs operating in rural areas of Punjab, Pakistan, which reported no sizable effects of microfinance on livestock, vehicles, and household assets such as electronics and appliances.

Regarding children's education, Zaidi et al. (2007) did not find any sizable impact, with the former study reporting a negative time-trend effect whereby borrowers with longer memberships were less likely to have their children enrolled in school. In fact, with regards to investment in assets, Zaidi et al. (2007) found that among six MFIs included in their study, only Kashf reported significant increases in the value of assets held by active borrowers relative to non-borrowers. For non-land asset value and non-farm asset ownership rates, the effect of microfinance was largely insignificant.

Maitroit and Zarazua (2017) conducted a systematic review of the quantitative literature of microfinance's impacts in the developing world, and develop a theory of change that links inputs to impacts on several welfare outcomes. Among their results they find that the limited comparability of outcomes and the heterogeneity of microfinancelending technologies, together with a considerable variation in socio-economic conditions and contexts in which impact studies have been conducted, render the interpretation and generalization of findings intricate. Microfinance induces short-term dynamism in the financial life of the poor; however, they do not find compelling evidence that this dynamism leads to increases in income, consumption, human capital and assets, and, ultimately, a reduction in poverty.

Efendic, V. and Hadziahmetovic, N. (2017), conducted a study about the "two dimensional" efficiency of microfinance institutions in Bosnia and Herzegovina ( $\mathrm{BiH})$. The study reveals even lower social efficiency, which is found at the level of 59\%, and which suggests that the potential for social efficiency improvements is $41 \%$. The given results reveal that MFIs are wasting their resources and there is significant potential to improve their technical efficiencies. This led to the conclusion that MFIs in BiH use too much labor (employees) and capital (assets) for the level of their outputs. In addition, the similar results for financial and social efficiency confirm that the scale of the operation is not the issue, since their scale efficiency is estimated at a level close to optimal. In their empirical investigation, they find a suboptimal level of both financial and social efficiency among MFIs in $\mathrm{BiH}$. However, financial efficiency is significantly higher than social efficiency, while small-sized MFIs over perform larger ones in both the financial and social dimensions. They conclude that MFIs in BiH should reconsider business policies and their operations, and put additional focus on reaching a larger number of clients.

\section{Poverty in Albania}

Poverty in Albania has a multidimensional character. It is not identified only by the unemployed or families living in economic poverty, but it also represents categories of people which are excluded from basic rights to have a house, adequate food, heating and clothing in winter, work in accordance with physical skills and education level, schools close to home and the opportunity to follow it, access to health services, protection from theft and violence, rights and free speech to demand their civil liberties. In Albania poverty in the new century mainly has affected the young generation. It dominates on the rural population, families with many members and children, the unemployed and people with lower education. The poorest group in Albania is the younger generation. More than $55 \%$ of the poor population is under 25 years, while this age group comprises only $33 \%$ of the total population. This is contrary to the popular perception that the groups most affected by poverty are seniors. On the contrary, only $10 \%$ of the poor population is 60 years or older. The unemployment rate increased from $12.5 \%$ in 2008 to $18 \%$ in 2014. The lack of jobs is more pronounced on vulnerable groups such as the youth and women. Continuous output gap and tensions in the labor market are reflected in the downward trend of the rate of participation in the workforce.

According to the joint report from the World Bank and INSTAT "Albania, the trend of poverty (Note 3)" poverty is not just a rural issue. There has been a shift of poverty from rural to urban areas, where the latter has experienced a large increase in poverty as a result of more focused effort towards rural development, while the continuous demographic movement from rural areas to urban areas has subsequently increased people living in poverty in urban areas. 
According to data from the World Bank over 2016 published in its recent Migration and Mobility (Note 4) report, $5.8 \%$ of the Albanian population lives in extreme poverty, while $34 \%$ live in poverty. Stronger growth stimulated job creation in 2016. In 2016 employment grew by 2.5 percentage points, reaching 48.7 percent, driven by industry (3 percent) and services (8.2 percent). Labor force participation increased to 57.5 percent, 1.8 percentage points higher than in 2015. The official unemployment rate declined by 1.9 percentage points to an average of 15.2 percent in 2016, with more than half of the unemployment still being long-term. Labor market recovery continued in the first half of 2017, with improvements in the employment rate (1.5 pp y-o-y) driven mostly by declining unemployment (2.3 pp y-o-y). Average nominal wages have been declining since the end of 2013, and might recover in 2017 helped by the end of the public wages freeze. Poverty is estimated to have declined as growth and employment continued to pick up. The poverty rate (measured as US\$ 5.5/day, $2011 \mathrm{PPP}$ ) is estimated to have decreased in 2016 to 33.9 percent, compared to 35.4 percent in 2015. For some households, the decline in nominal wages likely muted some of the progress taking place on employment outcomes, while the stabilization of remittances provides positive prospects for recipients. While labor force participation declined for women and youth in early 2017, this change was more than compensated by reductions in unemployment for these groups, resulting in slightly higher employment.

The microfinance sector represents $20 \%$ of the total number of loans granted in the country. A very high figure, which indicates the great needs for microfinance credits in the country. During these years, MFIs have lent to more than 350,000 small entrepreneurs, farmers and families, therefore injecting in the national economy more than 1 billion dollars.

The majority of MFIs operating in the world have a dual mission for social and financial impact, on the same line MFIs operating in Albania aim to achieve these goals. Among the main objectives of the Albanian MFIs are contributing to economic transition and boosting economic growth through promoting development of small and medium enterprises by supporting them with micro-credit. The microfinance institutions social mission is to contribute to the promotion of micro, small and medium enterprises, reduce poverty, improve living conditions of customers, empowering them, especially women and ethnic communities, provide support to the young generation and socially marginalized individuals or groups for the creation and development of their businesses and selfemployment opportunities and therefore increasing their clients wellbeing. MFIs operate in urban and rural areas, offering microcredit loans for SMEs and in some cases, technical assistance in the form of training. The purpose of MFI is to offer financial products and services that create value for customers, to improve their lives, and to improve commercial manufacturing or processing activities, handicrafts, and tourism activities.

In general, effective microfinance programs bring positive change at the individual level. They develop management skills of borrowers and increase the status and position not only in society but also in the home/family. Increasing social capacity due to microfinance programs leads to a change in the individual's income level, spending patterns, living conditions, awareness, accessibility, equality and justice in family and community activities, etc. Some important changes are:

- increased customer control over income resources within the economic portfolio in the family;

- increase of self-respect and respect from others;

- increase personal savings;

- a better position from which you start to face the future through more active behavior and an increased level of confidence.

From the questioner the people surveyed have replied to the question "weather they have ever applied for a loan?" $92 \%$ of respondents answered positively. So a large part of the respondents have benefited from banking services from NBFIs, after having met the conditions required of them to apply for loans. While the purpose for applying to get a loan was the most varied, most of them have applied for business loans, $47.3 \%$, followed by personal loans, $16.7 \%$, and loans for various home investments such as repairs or purchasing a new building, $12.1 \%$. Loans for education take about $7.5 \%$ of microloans approved, while loans for car purchases are about $6.98 \%$. There is a considerable percentage of loans being used for medical purposes, mainly for operations or medical visits outside the country. 


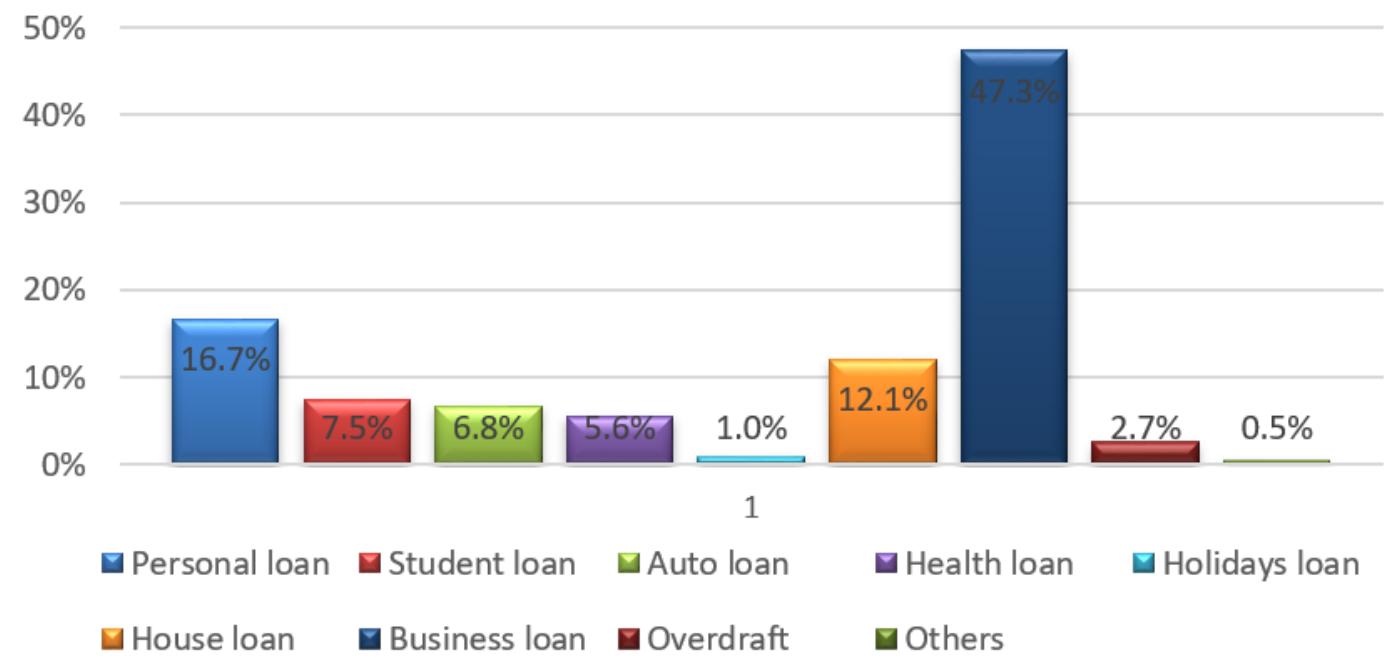

Figure 1. The purpose of the loan application

Source: Survey data. Author's work

Regarding access to microcredit, respondents who are in the first cycle of microcredit are $36 \%$, while the rest are former clients of other microfinance loan cycles. Around $42 \%$ of the respondents are in the second cycle of microcredit.

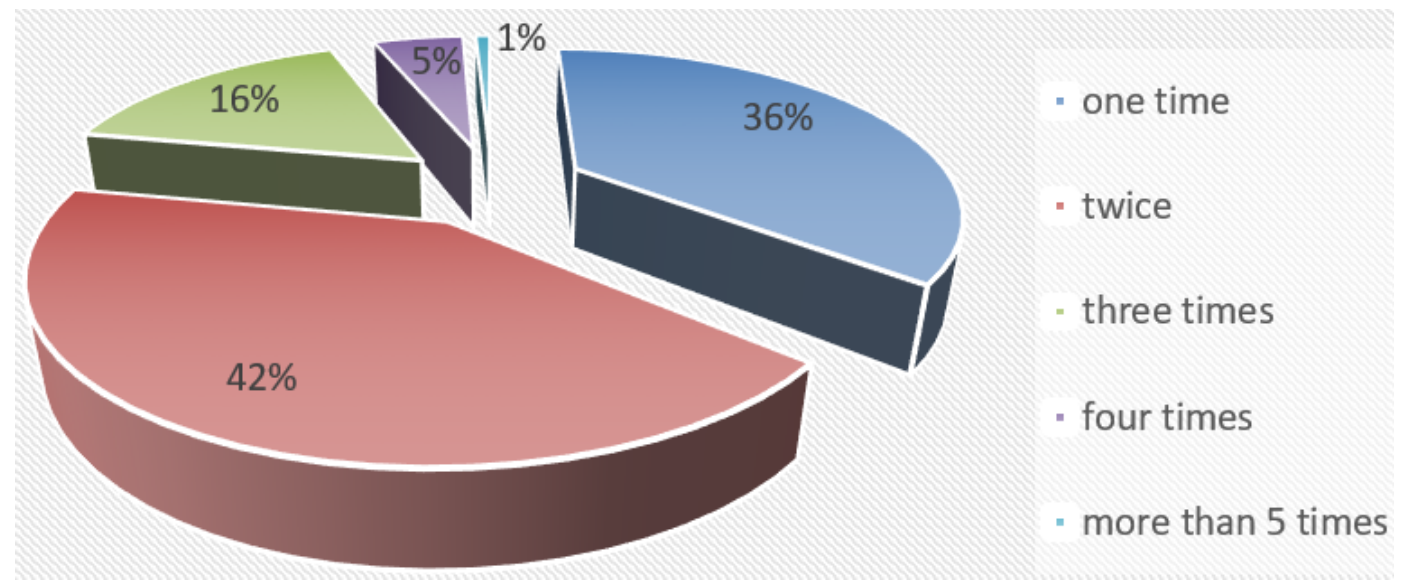

Figure 2. Distribution of times borrowers have received microcredit

Source: Survey data. Author's work

Asked what was the most difficult moment in the process of obtaining microcredit, $40 \%$ of borrowers chose "waiting for loan approval", 24\% of them describe as a delicate moment "researching for the right institution or bank", $21 \%$ of them "prepareing the necessary documents for a loan" and $15 \%$ of them "carefully understanding credit conditions" as interest rates, penalties, collateral requirements and other. Most of them see as a key moment waiting for the loan approval because the time factor is crucial, especially for certain types of investments in certain sectors of the economy such as agriculture and livestock. Also searching for the right financial institution represents an important moment because in the early stages of research borrowers select institution that offers more favorable conditions for them, in terms of the loan amount, interest rate, repayment terms and collateral requirements. 


\section{Waiting for loan approval \\ The search for the right bank or institution \\ Preparation of necessary documentation for loan \\ Understanding the credit conditions}

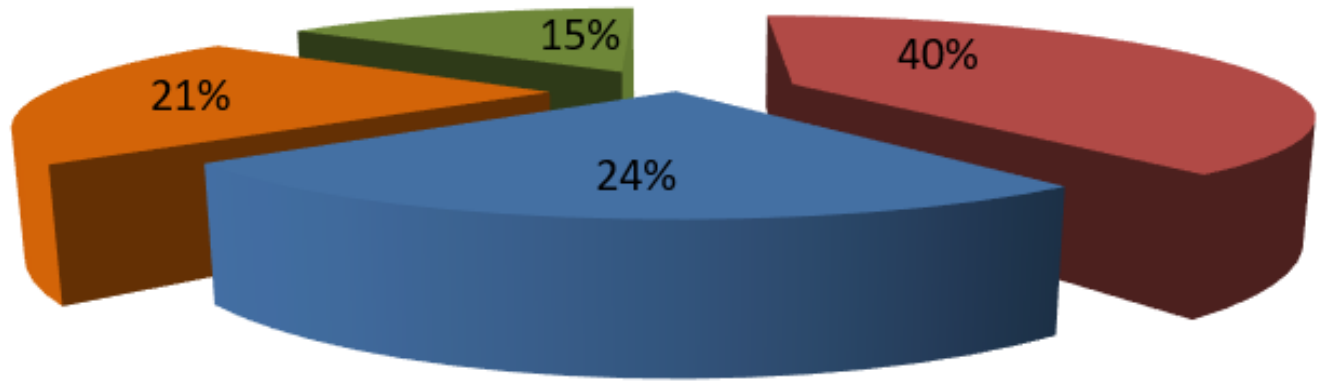

Figure 3. Which was the most difficult moment in obtaining credit loan?

Source: Survey data. Author's work

Among the factors that affect the demand for loans, interest rates have the greatest importance, followed by monthly installments, the required collateral, commissions, the loan repayment period and penalties in case of default.

\section{Evaluating the Impact of Micro Financial Services at the Individual Level}

H1. Expanding access to financial services for individuals (if microcredit loans are used for investments and not for consumption) will lead to the improvement of living standards for borrowers

Individuals use the money received from loans in various ways. They can use these resources for production, consumption and investment as well as for their own businesses. The use of cash is classified in two categories on the questionnaire by asking individuals for what they used the loan: for consumption or investment. Investments include the acquisition of land and property, purchasing of manufacturing equipment, machinery, raw materials, cattle, etc. Investments are also made in productive activities that generate income, and agricultural activities that generate goods and services to sell but also for personal consumption. Personal consumption includes spending on basic needs such as: health, education, house repair, vacation, and early repayment of debt.

The data gathered from the questionnaire will allow to give an answer on the hypothesis that if the loan is used for investment and not for consumption, it will be beneficial to the borrower. Through this data we will assess the impact access to microfinance has on the borrower.

\subsection{Choosing the Variables}

The impact microfinance has on income of individuals will be measured through a regression model where the elements taken into account are: the effect the longevity of microfinance has, the number of micro-credit loans, the use of the loan, personal features of the creditor (age, sex, residence), and the effect education has in increasing household income.

The loan duration presented in number of years will be a variable, as this will best reflect the progress and the effects microfinance has. Since microfinance's objective is to improve economic conditions primarily for poor borrowers, the data analysis will measure the impact of changes in the economic welfare of the clients. Individual characteristics of the borrower include age, gender, income level, education, employment or not, the number of family members working, except the head of the household. Micro-credit payment is difficult for large families, when the only one working is the borrower and he has dependents who do not work. In addition, it is expected that families with more members employed will be able to generate more income if other factors remain the same. Also, if families cope with any extraordinary events such as: illness, theft, death, fire, drought, floods, lost jobs, and business failure, in the last 12 months it will be very difficult to make the loan payments.

\subsection{Econometric Specifications}

Coleman (Note 5) uses the following equations to determine the impact of a specific microcredit program in a certain village: 


$$
\begin{array}{r}
B_{i j}=X_{i j} \alpha_{\beta}+V_{j} \beta_{\beta}+\epsilon_{i j} \\
Y_{i j}=X_{i j} \alpha_{\mathrm{Y}}+V_{j} \beta_{\mathrm{Y}}+B_{i j} \delta_{\mathrm{Y}}+\mu_{i j}
\end{array}
$$

$B_{i j}$ is the amount borrowed by the family member $\mathrm{i}$ in village $\mathrm{j}$;

$X_{i j}$ is the vector of the family members' characteristics;

$V_{j} \quad$ is the vector of the characteristics of the village;

$Y_{i j}$ is the income for his family which the impact is measured;

$\alpha_{\beta}, \beta_{\beta}, \beta_{Y}, \delta_{Y}$ and $\alpha_{Y}$ are parameters that need to be assessed.

$\epsilon_{i j}$ and $\mu_{i j}$ are errors which determine unmeasurable features of the village and income, that determine borrowing and earnings, $\delta \mathrm{Y}$ is the main parameter, because it measures the impact of microcredit on income.

Aghion and Morduch (2005) defined the following equation to determine the impact of variables specified in a certain moment of time $\mathrm{t}$.

$$
Y_{i j t}=X_{i j t} \alpha+V_{j} \beta+M_{i j} \gamma+T_{i j t} \delta+\eta_{i j t}
$$

The $\delta$ value must be determined, which is the coefficient of the variable that measures the impact. $Y_{i j t}$ is the dependent variable that measures the income or profits of the family member $i$ in a certain moment of time $t$ of the village j. $X_{i j t}$ gives the characteristics of borrower $\mathrm{i}$ in a certain moment of time $\mathrm{t}$ and $V_{j}$ is a vector of the dummy variable, the village, that is permanent over time. $M_{i j}$ is a vector of special specific variables, where choosing this individual program is not by accident and they are fixed over time. It may reflect, for example, the energy level of an individual, or management skills to run a business. In this case, they do not assume that this variable is visible. The same set of variables can be calculated once again in the period $t+1$; the following is the specification of the model.

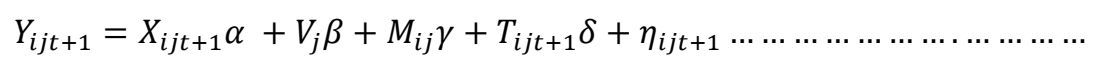

From the difference between equations 4 and 3 it is calculated the following:

$$
\Delta Y_{i j}=\Delta X_{i j} \alpha+\Delta C_{i j} \delta+\Delta \eta_{i j}
$$

Where $\Delta$ indicates the change in variables in between periods $\mathrm{t}+1$ and $\mathrm{t}$. In this equation the village dummy variable $V_{j}$ falls, as well as specific individual characteristics become fixed (non-observable inputs). A continuous assessment of the beneficial impact of $\delta$ can be taken into account (which is the most important purpose of the model).

Making a few modifications to the econometric models mentioned above, to measure the effect that microfinance has on household incomes we use the specified following equation:

$$
\begin{array}{r}
Y_{i}=\beta_{0}+\beta_{1} \text { LoanUse }_{i}+\beta_{2} \text { LoanTime }_{i}+\beta_{3} \text { Education }_{i}+\beta_{4} \text { Gender }_{i}+\beta_{5} \text { Age }_{i}+\beta_{6} \text { Residence }_{i}+ \\
\beta_{7} \text { FamilyMembWork }_{i}+\beta_{8} \text { xTakeLoan } \\
j
\end{array}
$$

Where:

The dependent variable: $Y_{i}$ is the increase of the individual borrower's family income level;

Independent variables are:

LoanUse $_{i}$ is the variable that has the value 1 if the loan is used for investments and 0 if the loan is used for personal consumption;

LoanTime $_{i}$ is the time (years) that the individual is participating in a micro-credit program from a MFI;

Education $_{i}$ is an individual characteristic of the borrower;

Gender $_{i}$ is an individual characteristic of the borrower;

$\mathrm{Age}_{i}$ is an individual characteristic of the borrower;

Residence $_{i}$ rural or urban areas, where the borrower resides;

FamilyMembWork $k_{i}$ the number of borrower's family members who are employed;

$x$ TakeLoan $_{j}$ is the number of times that the individual has received microcredit loans;

$\mu_{i}$ measures the idiosyncratic error; 
$\beta_{0}, \beta_{1}, \beta_{2}, \beta_{3}, \beta_{4}, \beta_{5}, \beta_{6}, \beta_{7}$ and $\beta_{8}$ are the unstandardized coefficients.

$\beta_{1}$ measures the difference between individuals who have received loans and have used it either for investments or personal consumption. Unstandardized coefficient $\beta_{2}$ measures the microfinance impact while the other unstandardized coefficients $\beta_{3}, \beta_{4}$, etc., represent the connection between the borrower's characteristics and various economic elements that need to be evaluated. An empirical regression analysis was conducted through the SPSS computer program, which shows that there is a link between the elements taken into consideration.

Table 2 shows a model summary of the connectivity between the increase of the household income level and the independent variables stated above considered in this hypothesis.

Table 2. Model summary of the connectivity between the increase of the household income level and the independent variables associated with the borrower

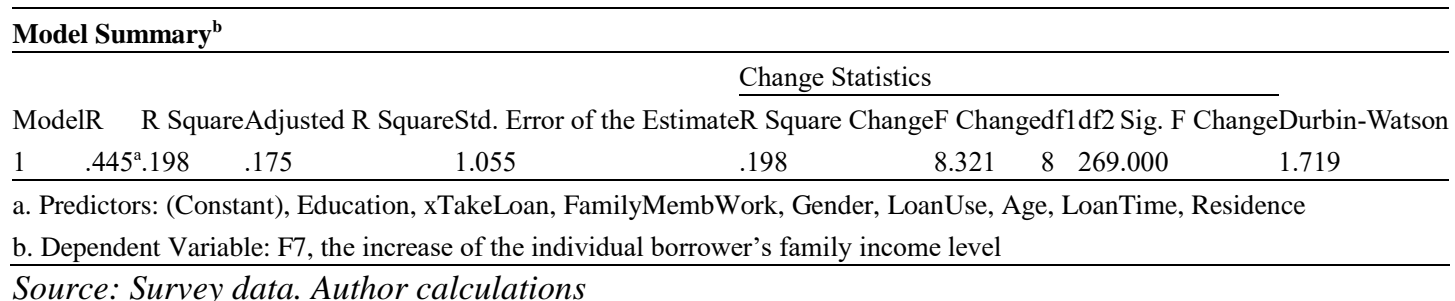

Source: Survey data. Author calculations

R-squared is a statistical measure of how close the data are to the fitted regression line. It is also known as the coefficient of determination, or the coefficient of multiple determination for multiple regression. $\mathrm{R}^{2}$ is expressed as the ratio of the explained variance (variance of the model's predictions, use of the loan, the length of a microcredit loan, education, gender, age, residence, etc.) to the total variance (sample variance of the dependent variable, the increase of household income level). This value indicates that $19.8 \%$ of the household income increase variance may depend on independent variables. Table 3 below is associated with the Anova coefficient and shows that "p value" (sig) is equal to 0.000 , so it is less than $\alpha=0.05$, therefore it can be concluded with a $95 \%$ probability that the increase in household income levels is affected by the independent variables included in the multiple linear regression model.

Table 3. Anova, H1. The link between increased household income levels and independent variables.

\begin{tabular}{llllll}
\hline ANOVA $^{\mathbf{a}}$ & \multicolumn{5}{l}{} \\
\hline Model & Sum of Squares & df & Mean Square & F & Sig. \\
\hline 1 Regression & 74.163 & 8 & 9.270 & 8.321 & $.000^{\text {b }}$ \\
Residual & 299.679 & 269 & 1.114 & & \\
Total & 373.842 & 277 & & & \\
\hline a. Dependent Variable: F7, the increase of the individual borrower's family income level & & \\
b. Predictors: (Constant), Education, xTakeLoan, FamilyMembWork, Gender, LoanUse, Age, LoanTime, Residence
\end{tabular}

Source: Survey data. Author calculations

Based on the correlationa coefficient table associated with the hypothesis H1 in Appendix 1, one can find the following unstandardized coefficients: $\beta_{1}, \beta_{2}, \beta_{3}, \beta_{4}, \beta_{5}, \beta_{6}, \beta_{7}$ and $\beta_{8}$.

The equation predicted by the multiple linear regression model is:

$$
\begin{array}{r}
Y_{i}=2.526+0.859 \text { UseLoan }_{i}+0.25 \text { LoanTime }_{i}+\left(-2.12 \text { Education }_{i}+0.065 \text { Gender }_{i}+0.074 \text { Age }_{i}+\right. \\
0.011 \text { Residence }_{i}+0.126 \text { FamilyMembWork }_{i}+\left(-0.27 x \text { TakeLoan }_{j}+\mu_{i j} \ldots \ldots \ldots \ldots \ldots .\right.
\end{array}
$$

Coefficient (parameter evaluation) is 0.859 for the variable "LoanUse". This means that for every unit of measurement that is used to increase the investment, the household income level increases by 0.859 units, while holding all other variables constant. The coefficient has a positive value, which is in accordance with the raised hypothesis that the use of microcredit loans in business investments leads to increased revenue and combining it with other independent variables improves the living conditions of borrowers. The coefficient for the variable "LoanTime" is 0.25 . This means that for every unit of measurement that increases the time of the loans, the 
household income level increases by 0.25 units, while holding all other variables constant. This is an expected result since the borrowers are clients of microfinance for a long time. During this time they have increased their savings and hence the effects and benefits are relatively positive for them compared with individuals who have a shorter time participating in microfinance. The variable coefficient for "Education" is -2.12, which portrays the education level of a microcredit borrower. This means that for every unit of measurement that the variable "Education" increases, the level of household income is reduced by -2.12 units, while holding all other variables constant.

If we look at the t-test student values the "t-test" value is -3.037 and "p-value" is 0.003 . So "p-value" is less than alpha, which means that the result is statistically significant. The coefficient is 0.065 respectively for the variable "gender", 0.074 for the variable "age", for the variable "residence" is 0.01 and 0.126 for the variable "number of family members employed". This means that for every measuring unit that increases these variables, the household income level grows correspondingly (coefficient $\mathrm{x}$ unit), while holding all other variables constant. The coefficient is -0.27 for the number of times approved a loan. This means that for every measuring unit that increases the variable "number of times", the household income level is reduced by -0.27 unit, but if we look at student t-test values one will notice that "t-test" is -0.353 and "p-value" is 0.724 . So "p-value" is greater than $\alpha$, which means that this result is not statistically significant.

The clients were also asked related to the impact microcredit has on some elements at the individual level. From Chart 4 shown below we can see that the benefits are highest for the family's economic situation, social well-being, self-esteem and acquiring family assets. For some individuals in particular, small loans from MFIs have had a significant impact in increasing their capacity for more profits and professional growth, by helping them in opening new businesses. These are precisely the individuals who have responded in receiving the highest impact from the benefits of a micro loan in terms of social welfare and increased self-esteem. Having access to microcredit has brought it more income for themselves and their families. This has given them a sense of accomplishment and confidence in their ability to do business. Their family assets have increased since a part of micro loans primarily consumer loans are used by borrowers to purchase household appliances and to improve the economic situation of the family. The impact has been lower in trying to provide better health care for themselves and their family members, education for their children and managing un-planned expenses.

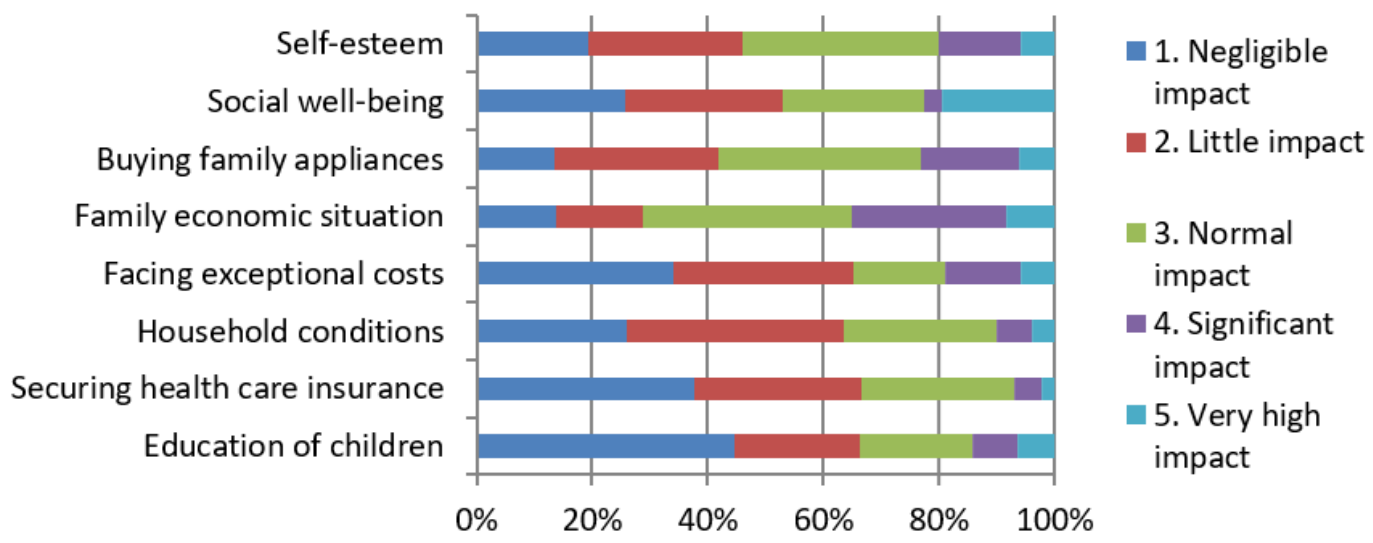

Figure 4. The impact of microcredit benefits at the individual level

Source: Survey data. Author's work

\section{Conclusions}

Hypothesis assessed the impact of widening the access to microcredit in order to improve the standard of living for borrowers, if the loan is used for investment purposes and not for personal consumption.

The results showed that there is a positive correlation between the variables that were considered important in this empirical study, this is indicated by the coefficient $R=44.5 \%$ and the "p-value" that is equal to 0.000 , less than $\alpha$ $=0.05$. Microcredit used for investments leads to increased living standards for borrowers, specifically it increases the income level. This is expected since many researchers around the world have concluded to the positive impact that microcredit has on low income families ore socially marginalized individuals or communities. It would be interesting to assess and compare the impact of micro credit loans in Albania if the borrowers would be poor people, but from data collected regarding their income level it was concluded that they are people with average socio-economic profiles and not poor people or belonging to marginalized groups. 


\section{References}

Al-Mamun, A. (2011). Examining the critical factors affecting the repayment of Microcredit. provided by Amanah Ikhtiar Malaysia.

Armendariz, A. B., \& Murdoch, J. (2005). The Economics of Microfinance. MIT Press; Cambridge, Massachusetts London, England.

Attanasio, O., Augsburg, B., Ralph, De H., Fitzsimons, E., \& Harmgart, H. (2011). Group lending or individual lending? Evidence from a randomized field experiment in Mongolia. Institute for Fiscal Studies IFS Working Papers W11/20.

Augsburg, B., De Haas, R., Harmgart, H., \& Meghir, C. (2013). Microfinance, Poverty and Education. National Bureau of Economic Research, Inc. NBER Working Papers 18538.

Augsburg, B., De Haas, R., Harmgart, H., \& Meghir, C. (2015). The Impacts of Microcredit: Evidence from Bosnia and Herzegovina. American Economic Journal: Applied Economics, 7(1), 183-203. https://doi.org/10.1257/app.20130272

Balkenhol, B., \& Guézennec, C. (2013). Le microcrédit professionnel en France: quels effets sur l'emploi"? Document de travail 2013-07. Paris: Centre d'Analyse Stratégique.

Banerjee, A. (2013). Microcredit under the microscope: What have we learned in the past two decades, and what do we need to know? Annual Reviews of Economics, 5, 487-519. https://doi.org/10.1146/annurev-economics082912-110220

Caroll, C., \& Weil, D. (1994). Saving and growth, a reinterpretation", Carnegie-Rochester Conference Series on Public Policy 40, 133-192 North-Holland. Pg. 153

Coleman, B. E. (1999). The Impact of Group Lending in Northeast Thailand. Journal of Development Economics, 60, 105-142. https://doi.org/10.1016/S0304-3878(99)00038-3

Copestake, J., \& Williams, R. (2011). What is the impact of microfinance, and what does this imply for microfinance policy and for future impact studies? Oxford: Oxford Policy Management.

Copestake, J., Dawson, P., Fanning, J. P., McKay, A., \& Wright-Revolledo, K. (2005). Monitoring the diversity of the poverty outreach and impact of microfinance: A comparison of methods using data from Peru. Development Policy Review, 23(6), 703-723. https://doi.org/10.1111/j.1467-7679.2005.00309.x

Doligez, F., Bédécarrats, F., Bouquet, E., Lapenu, C., \& Wampfler, B. (2013). Évaluer et mesurer l'impact de la microfinance: Sortir de la «double impasse. Revue Tiers Monde, 213(1), 161-78. https://doi.org/10.3917/rtm.213.0161

Duvendack, M., (2010a). Smoke and Mirrors: Evidence from Microfinance Impact Evaluations in India and Bangladesh. Unpublished PhD Thesis. School of International Development. Norwich: University of East Anglia.

Duvendack, M., Palmer-Jones, R., Copestake, J., Hooper, L., Loke, Y., \& Rao, N. (2011). What is the evidence of the impact of microfinance on the well-being of poor people? London: EPPI-Centre, Social Science Research Unit, Institute of Education, University of London.

Efendic, V., \& Hadziahmetovic, N. (2017). The Social And Financial Efficiency Of Microfinance Institutions: The Case Of Bosnia And Herzegovina. South East European Journal of Economics and Business, 12(2), 85-101. https://doi.org/10.1515/jeb-2017-0018

Eyben, R., et al. (2008). Conceptualizing Empowerment and the Implications for Pro-Poor Growth. A Paper for the DAC Poverty Network.

Ghalib, A. K., Malki, I., \& Imai, K. S. (2015). Microfinance and Household Poverty Reduction: Empirical Evidence from Rural Pakistan. Oxford Development Studies, 43(1), 84-104. https://doi.org/10.1080/13600818.2014.980228

Gloukoviezoff, G., Rebière, N., (2013). Etude d'impacts des microcrédits personnels garantis. Paris: 2G Recherche / Comptrasec / Caisse des dépôts

Hoxhaj, R. (2010). Regulation and supervision of microfinance in Albania. BEH - Business and Economic Horizons, 2(2), 75-81. https://doi.org/10.15208/beh.2010.19

Hulme, D. (2000). Is Microdebt Good for Poor People? A Note on the Dark Side of Microfinance. Small Enterprise 
Development, 11(1), 26. https://doi.org/10.3362/0957-1329.2000.006

Hulme, D., \& Mosley, P. (1996). Ch. 5 \& Analysis and Recommendations, In: "Finance Against Poverty", Volume I, London: Routledge.

INSTAT. (N/A). SHQIPËRIA: TRENDI I VARFËRISË 2002-2005-2008-2012. Retrieved from http://www.instat.gov.al/media/288396/anketa_e_matjes_se_nivelit_te_jeteses_2012_rishikuar.pdf

Johnson, S. (2004a). The impact of microfinance institutions in local financial markets: a case study from Kenya. Journal of International Development, 16(3), April. https://doi.org/10.1002/jid.1088

Khandker, S. R. (2005). Microfinance and Poverty: Evidence Using Panel Data from Bangladesh. The World Bank Economic Review, 19(2), 263-286. https://doi.org/10.1093/wber/lhi008

Lakwo, A. (2006). Microfinance, rural livelihoods, and women's empowerment in Uganda. (Doctoral Dissertation). Radboud University Nijmegen, Leiden, the Netherlands.

Maîtrot, M., \& Niño-Zarazúa, M. (2017). Poverty and wellbeing impacts of microfinance: What do we know? WIDER Working Paper 2017/190.

Morduch, J. (1998). Does Microfinance Really Help the Poor? New Evidence from Flagship Programs in Bangladesh. New York: New York University.

Morduch, J. (1999). The microfinance promise. Journal of Economic Literature, 37(4), 1569-1614. https://doi.org/10.1257/jel.37.4.1569

Mosedale, S. (2005). Assessing women's empowerment: towards a conceptual framework. Journal of International Development, 17, 243-257. https://doi.org/10.1002/jid.1212

Mosley, P., \& Hulme, D. (1998). Microenterprise finance: Is there a conflict between growth and poverty alleviation? World Development, 26(5), 783-790. https://doi.org/10.1016/S0305-750X(98)00021-7

Odell, K. (2010). Measuring the Impact of Microfinance - Taking Another Look. Grameen Foundation Publication Series. Washington D.C.: Grameen Foundation.

Rai, A., \& Ravi, S. (2011). Do Spouses Make Claims? Empowerment and Microfinance in India. World Development, 39(6), 913-921. https://doi.org/10.1016/j.worlddev.2009.10.019

Tarozzi, A., Desai. J., \& Johnson, K. (2013). On the Impact of Microcredit: Evidence from a Randomized Intervention in Rural Ethiopia. Barcelona Graduate School of Economics Working Papers 741.

World Bank Group. (2017). Migration and Mobility, Europe and Central Asia Economic Update.

Wright-Revolledo, K. (2005). The Darker Side to Microfinance: Evidence from Cajamarca, Peru". In J. Fernando (ed.). The Perils and Prospects of Microfinance: Globalization, Neo-liberalism and the Cultural Politics of Empowerment. London: Routledge.

Zaidi, A., Jamal, H., Javeed, S., \& Zaka, S. (2007). Social Impact Assessment of Microfinance Programmes in Pakistan. Draft Report. Islamabad: European Union-Pakistan Financial Services Sector Reform Programme.

\section{Notes}

Note 1. http://www.gdrc.org/icm/model/model-fulldoc.html

Note 2. Al-Mamun, 2011, Examining the critical factors affecting the repayment of Microcredit provided by Amanah Ikhtiar

Note 3. http://www.instat.gov.al/media/288396/anketa_e_matjes_se_nivelit_te_jeteses_2012_rishikuar.pdf

Note 4. http://documents.worldbank.org/curated/en/445651508415857577/pdf/120539-replacement-PUBLIC.pdf

Note 5. Coleman, B. E. (1999). The Impact of Group Lending in Northeast Thailand. Journal of Development Economics, 60, 105-142. 


\section{APPENDIX 1}

Table 1. Descriptive statistics H1

\begin{tabular}{llll}
\hline & Mean & Std. Deviation & $\mathrm{N}$ \\
\hline F7 & 2.88 & 1.162 & 278 \\
LoanUse & .66 & .475 & 278 \\
xTakeLoan & 2.20 & .944 & 278 \\
LoanTime & 2.73 & 1.479 & 278 \\
FamilyMembWork & .82 & .385 & 278 \\
Age & 3.47 & 1.123 & 278 \\
Gender & .42 & .495 & 278 \\
Residence & .49 & .501 & 278 \\
Education & 2.91 & 1.099 & 278 \\
\hline
\end{tabular}

Table2. Coefficients

\begin{tabular}{|c|c|c|c|c|c|c|c|c|c|c|c|c|}
\hline \multirow[b]{4}{*}{ Model } & \multirow{3}{*}{\multicolumn{2}{|c|}{$\begin{array}{l}\text { Unstandardized } \\
\text { Coefficients } \\
\end{array}$}} & \multirow{3}{*}{$\begin{array}{l}\text { Standardized } \\
\text { Coefficients } \\
\end{array}$} & & & \multicolumn{7}{|l|}{$95.0 \%$} \\
\hline & & & & & & \multicolumn{5}{|c|}{ Confidence } & \multirow{2}{*}{\multicolumn{2}{|c|}{$\begin{array}{l}\text { Collinearity } \\
\text { Statistics }\end{array}$}} \\
\hline & & & & & & \multicolumn{2}{|c|}{ Interval for B } & \multicolumn{3}{|c|}{ Correlations } & & \\
\hline & $\mathrm{B}$ & $\begin{array}{l}\text { Std. } \\
\text { Error }\end{array}$ & Beta & $\mathrm{t}$ & Sig. & $\begin{array}{l}\text { Lower } \\
\text { Bound }\end{array}$ & $\begin{array}{l}\text { Upper } \\
\text { Bound }\end{array}$ & $\begin{array}{l}\text { Zero- } \\
\text { order }\end{array}$ & Partial & Part & Tolerance & VIF \\
\hline (Constant) & 2.526 & .381 & & 6.626 & .000 & 1.775 & 3.276 & & & & & \\
\hline LoanUse & .859 & .148 & .351 & 5.784 & .000 & .566 & 1.151 & .375 & .333 & .316 & .808 & 1.237 \\
\hline xTakeLoan & -.027 & .076 & -.022 & -.353 & .724 & -.177 & .123 & .088 & -.022 & -.019 & .781 & 1.281 \\
\hline LoanTime & .025 & .049 & .032 & .520 & .604 & -.071 & .122 & .054 & .032 & .028 & .765 & 1.308 \\
\hline FamilyMembwork & .126 & .175 & .042 & .725 & .469 & -.217 & .470 & -.082 & .044 & .040 & .892 & 1.121 \\
\hline Age & .074 & .063 & .071 & 1.174 & .241 & -.050 & .198 & .199 & .071 & .064 & .807 & 1.239 \\
\hline Gender & .065 & .137 & .028 & .476 & .634 & -.204 & .335 & .140 & .029 & .026 & .877 & 1.141 \\
\hline Residence & .011 & .151 & .005 & .074 & .941 & -.286 & .308 & .222 & .004 & .004 & .706 & 1.417 \\
\hline Education & -.212 & .070 & -.200 & -3.037 & .003 & -.349 & -.074 & -.255 & -.182 & -.166 & .684 & 1.462 \\
\hline a. Dependent Varial & le: F7 & & & & & & & & & & & \\
\hline
\end{tabular}

\section{Histogram H1}

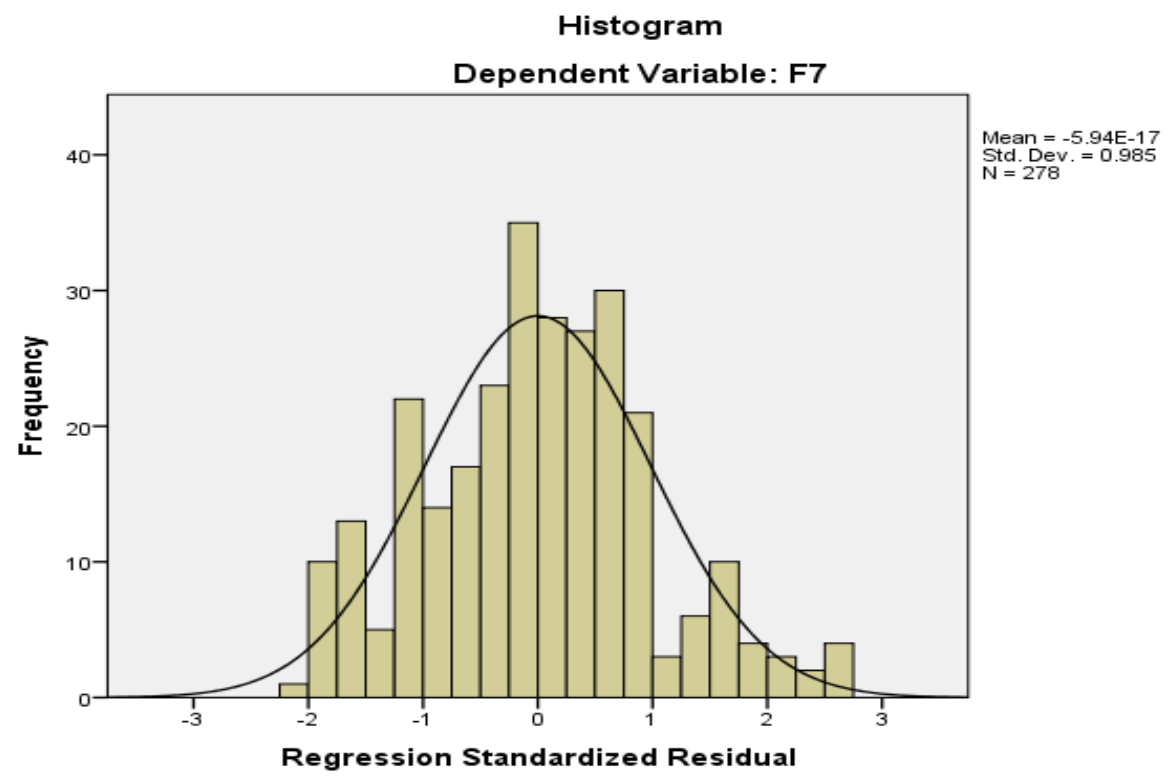




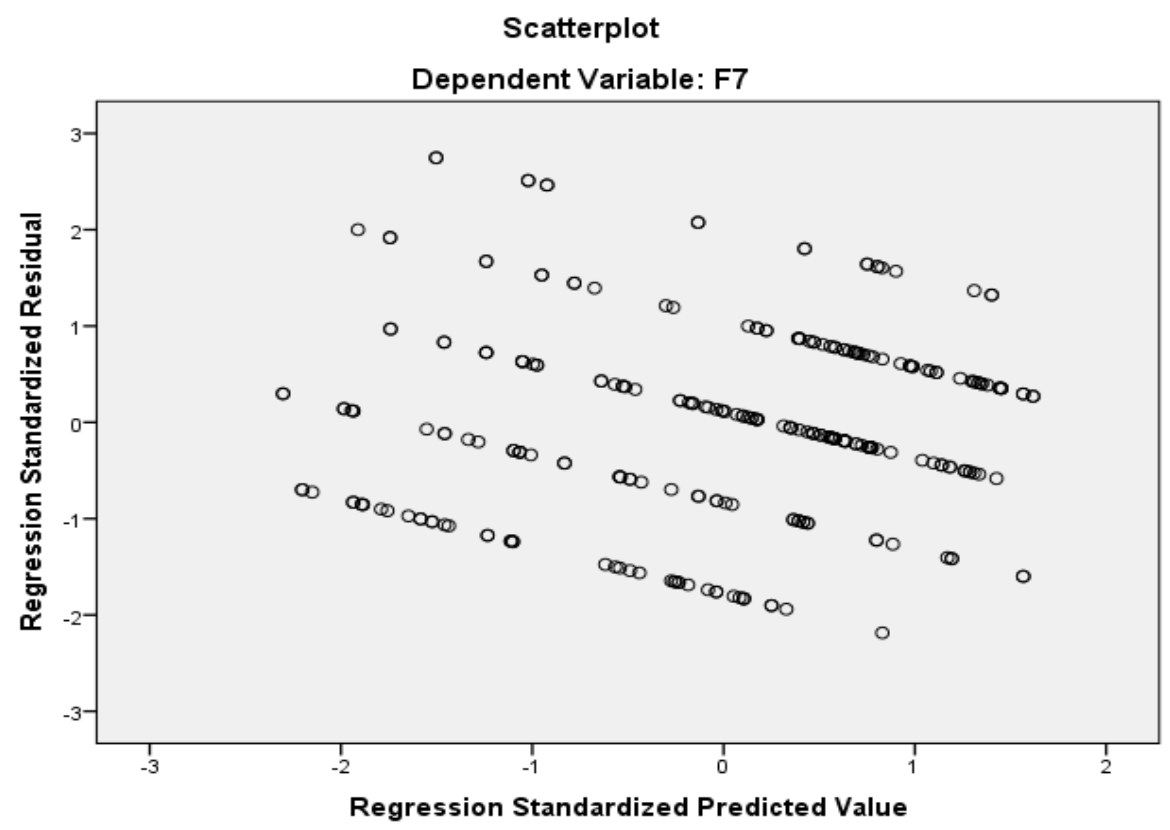

\section{Normal P-P Plot of Regression Standardized Residual}

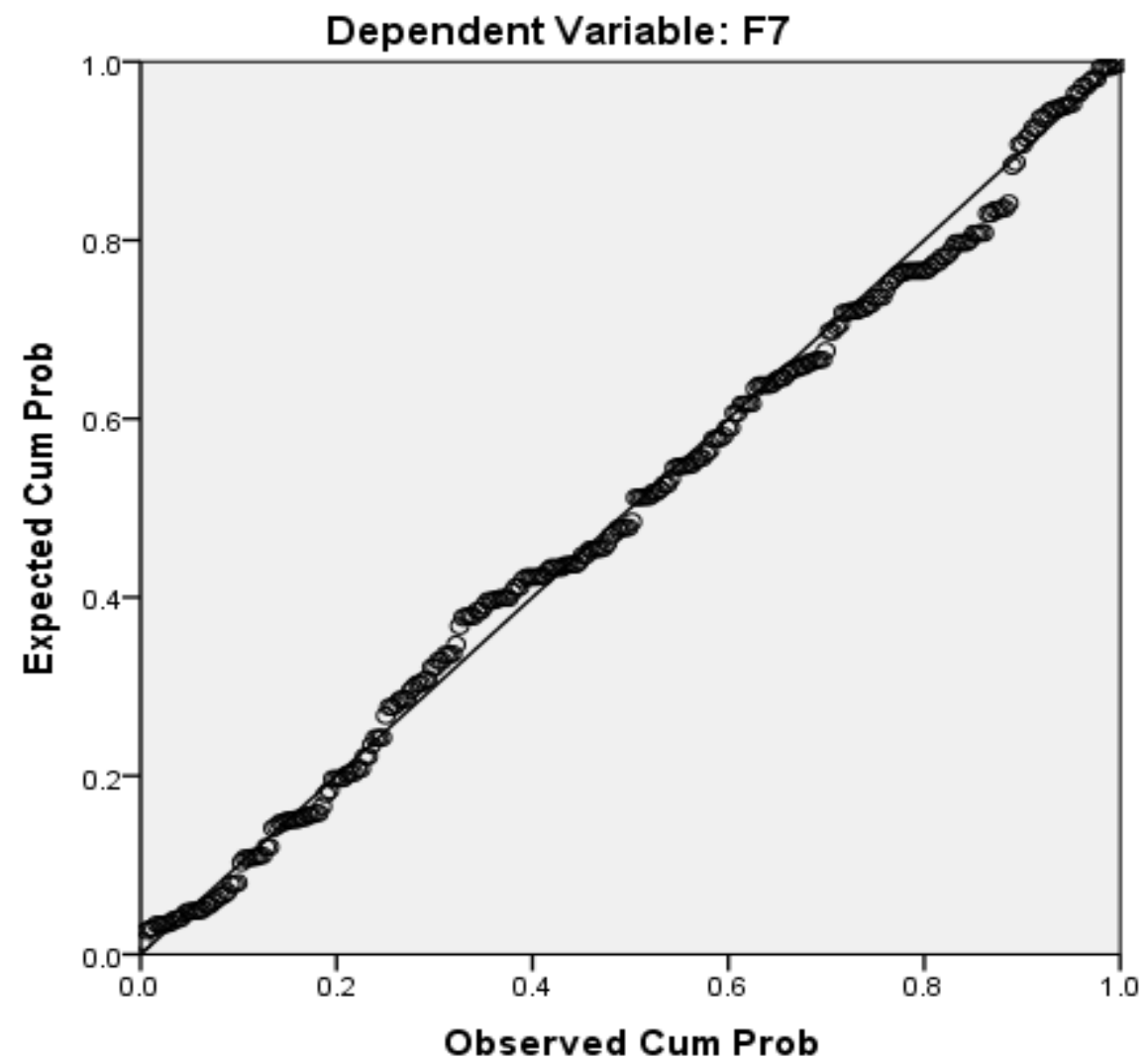

\section{Copyrights}

Copyright for this article is retained by the author(s), with first publication rights granted to the journal.

This is an open-access article distributed under the terms and conditions of the Creative Commons Attribution license (http://creativecommons.org/licenses/by/4.0/). 